\title{
Elmada Bazı Özelliklerin Birlikte Ele Alınabilme Potansi- yelleri: Pinova Örneği
}

\author{
Potentials of Some Properties to be Evaluated Together in Apple: Pinova Example
}

\section{Mehmet POLAT*}

Isparta Uygulamalı Bilimler Üniversitesi, Ziraat Fakültesi, Bahçe Bitkileri Bölümü, Isparta mehmetpolat@isparta.edu.tr

(iD) 0000-0002-2415-4229

\section{Kerem MERTOĞLU*}

Eskişehir Osmangazi Üniversitesi, Ziraat Fakültesi, Bahçe Bitkileri Bölümü, Eskişehir kmertoglu@ogu.edu.tr

iD 0000-0002-0490-9073

\section{İlknur ESKİMEZ}

Isparta Uygulamalı Bilimler Üniversitesi, Ziraat Fakültesi, Bahçe Bitkileri Bölümü, Isparta

iD 0000-0003-4443-505X

*Sorumlu yazar

Gönderilme Tarihi : 27 Mayıs 2020

Kabul Tarihi

: 25 Ağustıs 2020

\section{Özet}

$\mathrm{Bu}$ çalışma, Pinova çeşidi kullanılarak, elmada, üretici veya tüketici açısından önem arz eden bazı özelliklerin birbirleri ile olan ilişkilerini belirlemek amacı ile yürütülmüştür. Araştırma bulguları doğrultusunda; verim, tam çiçeklenmeden hasada geçen süre (TÇHGS), meyve eni, boyu, ağırlı̆̆ı, sertliği, L, a, b, suda çözünebilir kuru madde (SÇKM), titre edilebilir asit (TEA) ve $\mathrm{pH}$ değerlerinin sıras1 ile ortalama olarak, $21.65 \mathrm{~kg}$ ağaç-1, 144.00 gün, $66.87 \mathrm{~mm}, 58.01 \mathrm{~mm}, 133.63 \mathrm{~g}, 7.73 \mathrm{~kg} \mathrm{~cm}^{-1}, 43.51,26.57$, $16.07, \% 11.40, \% 0.51$ ve 4.39 değerlerinde olduğu tespit edilmiştir. Verim artışı, SÇKM, TEA, meyve boyutları ve ağırlığ1 özelliklerinde düşüşe sebep olurken, kabuk üst a değeri bu özellikler ile pozitif korelasyon içerisinde bulunmuştur. Meyve boyutları ve ağırlığı özellikleri kendi aralarında yüksek düzeyde pozitif ilişki gösterirken, meyve eti sertliği ile tersi ilişki içerisinde tespit edilmiştir. pH ile yüksek seviyede negatif ilişki içerisinde bulunan, TEA'nın, SÇKM birikimini tetiklediği tespit edilmiştir. Elde edilen sonuçların, yetiştiricilikte kültürel işlemlere yön verebileceği düşünülmektedir. 
Anahtar kelimeler: Elma, korelasyon, meyve kalitesi, verim, Pinova

Abstract: This study was conducted with the aim of determining the relationships of some characteristics that are important for the producer or consumer in apple using the Pinova cultivar. According to results; average values of yield, day from full bloom to harvest (DFBH), fruit width, length, weight, hardness, L, a, b, soluble solid content (SSC), titratable acidity (TA) and $\mathrm{pH}$ properties were $21.65 \mathrm{~kg}$ tree $^{-1}, 144.00$ days, $66.87 \mathrm{~mm}, 58.01 \mathrm{~mm}, 133.63 \mathrm{~g}, 7.73$ pounds, $43.51,26.57,16.07,11.40 \%, 0.51$ and 4.39, respectively. Yield increase led to decrease in SSC, TA, fruit sizes and weight characteristics, while the over a value was positively correlated with these characteristics. Whereas fruit sizes and weight properties showed a high level of positive relationship between themselves, fruit flesh hardiness was inversely correlated with these properties. It was determined that TA, which has a high level of negative relation with $\mathrm{pH}$, triggered the accumulation of SSC. It is thought that obtained results may lead to cultural processes in cultivation.

Keywords: Apple, correlation, fruit quality, yield, Pinova

\section{Giriş}

Türkiye, jeopolitik konumu sayesinde farklı iklim türlerini bir arada barındırmakta olup, zengin tür ve çeşit potansiyeli gösteren ülkelerden biridir. Genetik tabanı çok geniş olan elma, ekolojik zenginliği yüksek olan ülkemizin, her bölgesinde yetiştirilse de, Orta Anadolu ve Akdeniz Bölgesi tarımı ve ticaretinde öne çıkmaktadır (Cennet ve Karaçayır, 2009).

Ülkemiz, elma türünde, üretici ülkeler arasında olmasına rağmen, ticaretinde potansiyelinin oldukça gerisindedir (Özçatalbaş ve ark., 2009). Bu sebeple, üretimin büyük bir kısmı iç piyasada taze olarak tüketilmekte, kurutularak veya işlenerek farklı şekillerde değerlendirilmektedir (Cennet ve Karaçayır, 2009). Arzın fazla, ihracatın düşük düzeyde seyretmesi ise fiyatların düşük düzeyde kalmasına sebep olarak, çiftçiyi elma tarımından uzaklaştırmaktadır. Bu durum, üretilen üründe standardizasyonun yakalanması yoluyla iyileştirilebilir. Nitekim, ürünün nitel ve nicel kalitesinde eksiklikler bulunması nedeniyle gümrüklerden dönen ürün miktarı azımsanamayacağı gibi alıcı ülkelerin, ülkemize bakış açıları ve gelecek projeksiyonunda ticari ilişkileri de kötümser olabilmektedir (Özçatalbaş ve ark., 2009).

Üretimin ekonomik, sürdürülebilir ve kaliteli olmasında en önemli kıstas ekolojiye uygun çeşit ve anaç seçimi, olmasına rağmen, uygulanan kültürel işlemlerinde bu parametreler üzerine olan etkileri oldukça önemlidir (Li ve ark., 2012; Taysı ve Çelik, 2017). Bu noktada, çiftçinin, doğru müdahaleler ile yetiştiriciliği yönetmesi son derece önemlidir.

Meyve tutum miktarının yükselmesi, verim artışını sağlamasına rağmen, pomolojik ve kimyasal özelliklerde düşüşe sebep olmaktadır (Reig ve ark., 2016; Mertoğlu ve ark., 2019). Bu durumda, seyreltmenin önemine değinilebilir. Sik dikimin tercih edilmesi durumunda, 
özellikle fungal hastalıkların epidemisinde artışa sebep olurken, hava sirkülasyonunun ve güneş 1şığının etkin kullanımını azalttığından, renklenme problemlerine sebep olabilmektedir. Renklenmede meydana gelen noksan, meyvelerin fiziksel özelliklerinde de düşüşe sebep olmaktadır. Budama şekli bu faktörler üzerine etki eden diğer bir unsur olup, goble budamanın bu noktada daha iyi sonuçların alınmasına zemin hazırladığı ifade edilmektedir.

Doğru gübreleme, malç kullanımı veya su kısıtı gibi uygulamalar, meyvelerin biyokimyasını iyileştirmede alternatif olarak kullanılan yöntemlerdir (Tustin ve ark., 2001; Li ve ark., 2012; İmrak ve ark., 2019).

Tarımsal üretimde, ürünün nihai şekli ve kompozisyonu üzerine ekolojik faktörlerin (1ş1k, nem, sıcaklık, toprak bünyesi ve faunası vb.) ve kültürel uygulamaların etkisi (yetiştiricilik sistemi, sulama, gübreleme vb. ) kümülatif olup, birbiriri ile interaksiyon halinde olan tüm özellikler bu durumdan etkilenmektedir. $\mathrm{Bu}$ çalışma, M9 bodur elma anacı üzerine aşılı 'Pinova' çeşidinin fenolojik, pomolojik ve kimyasal özelliklerinin birbirleri ile nasıl bir etkileşim halinde olduğunun tespit edilmesine

\section{Materyal ve metot \\ Materyal}

Çalışma, 2017 ve2018yılında Isparta Uygulamalı Bilimler Üniversitesi, Ziraat Fakültesi, Bahçe Bitkileri bölümüne ait elma deneme parselinde yürütülmüştür. Materyal olarak, M9 anacina aşı1ı halde, 2004 yılında, 3.5 x 1 m sıra arası ve sıra üzeri mesafe olacak şekilde dikilen 'Pinova' çeşidi kullanılmıştır. Deneme alanında, damla sulama yöntemi kullanılmakta olup, kültürel işlemler her iki deneme yılında da düzenli

Çizelge 1. Araştırma alanına ait ekolojik veriler

\begin{tabular}{|c|c|c|c|c|c|c|c|c|c|}
\hline \multicolumn{10}{|c|}{ Araştırma alanına ait iklimsel özellikler } \\
\hline & \multicolumn{3}{|c|}{ Sicaklik $\left({ }^{\circ} \mathrm{C}\right)$} & \multicolumn{3}{|c|}{ Yağıș (mm) } & \multicolumn{3}{|c|}{ Nispi nem (\%) } \\
\hline & Uzun yıllar & 2017 & 2018 & Uzun yillar & 2017 & 2018 & Uzun yıllar & 2017 & 2018 \\
\hline Mart & 5.9 & 7.3 & 9.2 & 59.1 & 74.4 & 69.3 & 66.0 & 64.1 & 65.9 \\
\hline Nisan & 10.7 & 10.6 & 14.2 & 52.9 & 25.6 & 6.3 & 61.5 & 59.6 & 51.0 \\
\hline Mayis & 15.4 & 14.9 & 16.8 & 56.7 & 149.5 & 62.9 & 59.2 & 63.7 & 62.3 \\
\hline Haziran & 19.8 & 20.1 & 20.0 & 33.6 & 30.9 & 69.4 & 52.5 & 58.9 & 62.4 \\
\hline Temmuz & 23.4 & 25.2 & 24.3 & 16.3 & 13.1 & 4.1 & 45.7 & 41.9 & 46.9 \\
\hline Ağustos & 23.2 & 23.8 & 24.3 & 14.3 & 20.4 & 14.2 & 46.4 & 52.1 & 47.6 \\
\hline Eylül & 18.8 & 21.0 & 20.7 & 18.8 & 5.7 & 1.6 & 52.3 & 45.1 & 47.6 \\
\hline \multicolumn{10}{|c|}{ Araştırma alanına ait toprağın fiziksel ve kimyasal özellikleri } \\
\hline $\begin{array}{l}\text { Toprak } \\
\text { Tekstürü }\end{array}$ & $\mathrm{pH}$ & $\begin{array}{c}\text { Tuzlulu } \\
(\%)\end{array}$ & & $\mathrm{CaCO}_{3}(\%)$ & $\begin{array}{c}\text { Organik } \\
\text { Madde } \\
(\%)\end{array}$ & $\begin{array}{c}\text { Elverişli } \\
\mathrm{P}_{2} \mathrm{O}_{5}(\mathrm{~kg} / \\
\text { da) }\end{array}$ & Elverişli & i $\mathrm{K}_{2} \mathrm{O}$ & $\mathrm{kg} / \mathrm{da})$ \\
\hline Killi-Tınlı & 8.07 & 0.02 & & 22.2 & 2.7 & 4.8 & & 72.0 & \\
\hline
\end{tabular}


şekilde yapılmıştır. Araştırma alanının rakımı 1009 metre olup, deneme parseline ait ekolojik özellikler Çizelge 1'de verilmiştir.

Deneme yerinin toprak yapısı, orta derece alkali karakterde olup, kireç içeriği yüksektir. Organik madde miktarı orta düzeyde olan deneme yerinin, ekstrakte edilebilen P içeriği ve toprak tuzluluğu düşük, $\mathrm{K}$ içeriği ise yeterli düzeyde tespit edilmiştir (Jackson, 1962). Çalışma alanına ait iklimsel verilerde ise, aylara ait ölçülen ortalama sıcaklık değerlerinin, küresel 1sınmanın etkisi ile genel olarak uzun yıllara nazaran yüksek olduğu görülmüşstür. Yağış miktarı bakımından, uzun yıllar verileri incelendiğinde, mevsimlerin ayları arasında tutarlılık olduğu görülürken, çalışmayı kapsayan yıllarda düzensiz yağışlar ve kurak dönemler gözlemlenmiştir. Hava oransal neminde ise, uzun yıllara göre özellikle yaz döneminde bir artış eğilimi olduğu tespit edilmiştir.

\section{Fenolojik gözlemler}

Çiçek tomurcuklarının \% 70-80 oranında çiçek açtığ1 evre, tam çiçeklenme zamanı olarak kaydedilmiştir. Meyvelerin hasat edilmesinde; renk, absisyon tabakası oluşumu ve tat kriter olarak dikkate alınmıştır. Tam çiçeklenme tarihi ile hasat tarihi arasında geçen toplam gün sayısı bulunarak, tam çiçeklenmeden hasada kadar geçen süre (TÇHGS) hesaplanmıştır (Karaçalı, 2012).

\section{Pomolojik özellikler}

Hasat edilen meyveler, bekletilmeden pomolojik ölçümler için laboratuvara getirilmiştir. Meyve ağırlığı, 0.001 g'a duyarlı elektronik terazi
(Vibra, AJH-42OCE), meyve eni ve boyu ise 0.01 mm'ye duyarlı dijital kumpas yardımı ile ölçülmüştür. Meyve eti sertliği dijital el penetrometresi (FT-327) ve kabuk üst renk değerleri ise renk ölçer (Minolta CR-400) vasıtası ile belirlenmiştir (Karaçalı, 2012).

\section{Kimyasal özellikler}

Kimyasal özellikler, meyve sularında ölçülmüştür. Bu amaç doğrultusunda, meyveler, katı meyve suyu sıkacağı aracılığı ile meyve suyuna dönüştürülerek, Whatman kağıtları ile süzülmüştür. Suda çözünebilir kuru madde miktarı (SÇKM), dijital refraktometre (Hanna, HI 96801) aracılığg ile ölçülmüş ve sonuçlar yüzde (\%) olarak verilmiştir (Karaçalı, 2012). Titre edilebilir asitlik tayininde, meyve suları, fenolftalein indikatörlüğünde, $0.1 \mathrm{~N}$ Sodyum hidroksit çözeltisi ile titre edilmiş, renk değişiminin geri dönmediği noktada okunan sarfiyat değeri, Karaçalı (2012) tarafından belirtilen formüle göre uyarlanarak, hakim asit olan, malik asit cinsinden, \% olarak ifade edilmiştir.

\section{İstatistiksel yöntem}

Araştırma, tesadüf parselleri deneme desenine göre tasarlanarak, on tekerrürlü (ağaç) yürütülmüştür. Pomolojik özelliklerde, her tekerrürde, ağacin dört tarafindan toplanan yirmişer meyve üzerinde ölçümler yapılmıştır. Kimyasal analizler için, pomolojik ölçümleri tamamlanan meyveler, katı meyve suyu sıkacağ 1 vasitası ile meyve suyuna dönüştürülerek, analizlerde kullanılmıştır. İncelenen özelliklere ait tanitic1 istatistikler ve korelasyon katsayılarının elde edilmesinde, Minitab-17 
paket programından faydalanılmış, sonuçlar iki yılı kapsayacak şekilde verilmiştir (Zar, 2013).

\section{Bulgular ve Tartışma}

Pinova çeşidinin, Isparta ekolojisinde, yeme olumuna gelebilmesi için, tam çiçeklenmeden hasada 144 güne ihtiyaç duyduğu tespit edilmiştir (Çizelge 2). Aynı çeşit için bu sürenin Makedonya'da 158 gün olduğu bildirilmektedir (Kiprijanovski, 2007). Legave ve ark. (2008), bitkinin fenolojik seyrine etki eden en önemli faktörün sicaklık olduğunu ve bu sürenin, sıcaklık artışı ile kısaldığı, serin seyreden iklim şartlarında ise uzadığı bildirilmektedir (Mertoğlu ve Evrenosoğlu, 2017). Ayrica, uygulanan kültürel işlemler, anaç, meyve tutum miktarı ve yetiştiricilik yapılan alanda hüküm süren ekolojik faktörler de, fenolojik özellikler üzerine oldukça önemlidir.
Araştırmada, ağaç başına verim $21.65 \mathrm{~kg}$ ağaç ${ }^{-1}$ olarak bulunmuştur (Çizelge 2). Farklı çalışmalarda, aynı çeşide ait verim değerlerinin yıllar bazında farklılık gösterdiği belirlenmiş olup, bu değerin yıllara göre 25.1 ve $31.1 \mathrm{~kg}$ ağaç-1 (Kiprijanovski, 2007), 12.3, 12.5 ve 14.9 kg ağaç-1 (Czynczyk ve ark., 2005) düzeylerinde değişim gösterdiği bildirilmektedir. Çalışmadan elde edilen verim değerleri, literatür sınırları içerisinde belirlenmiş olup, çalışmadan çalışmaya farklılık gösteren bu değer üzerine, ağacin içerisinde bulunduğu fizyolojik durum (yaş) ve tercih edilen yetiştiricilik sisteminin (bodur - yarı bodur - geleneksel gibi) etkisi oldukça önemlidir.

Sofralık tüketime yönelik meyve yetiştiriciliğinde, tüketici tercihini yönlendiren pomolojik özelliklerin, üstün olmasında yarar

Çizelge 2: İncelenen özelliklerin değişim aralıkları ve ortalama değerleri

\begin{tabular}{llll}
\hline & Minimum & Maximum & Ortalama \\
\hline TCHGS (gün) & 140.0 & 148.0 & $144.00 \pm 2.29$ \\
Verim (kg/ağaç) & 19.05 & 27.90 & $21.65 \pm 2.86$ \\
Meyve eni (mm) & 50.58 & 81.88 & $66.87 \pm 6.15$ \\
Meyve boyu (mm) & 43.15 & 72.13 & $58.01 \pm 5.61$ \\
Meyve ağırlı̆̆ (g) & 59.05 & 227.87 & $133.63 \pm 35.64$ \\
Sertlik (kg cm-1) & 6.00 & 10.20 & $7.73 \pm 0.82$ \\
L & 30.33 & 67.88 & $43.51 \pm 7.83$ \\
A & -4.67 & 35.64 & $26.57 \pm 8.88$ \\
B & 9.52 & 26.42 & $16.07 \pm 3.44$ \\
SÇKM (\%) & 9.60 & 14.10 & $11.40 \pm 1.15$ \\
TEA (\%) & 0.38 & 0.68 & $0.51 \pm 0.10$ \\
pH & 4.26 & 4.56 & $4.39 \pm 0.09$ \\
\hline
\end{tabular}


vardır. Bu bağlamda, meyve eni, boyu, ağırlığ ve sertliği özelliklerinin sırası ile 50.58-81.88 mm, 43.15-72.13 mm, 59.05- $227.87 \mathrm{~g}$ ve 6.0-10.20 $\mathrm{kg} \mathrm{cm}{ }^{-2}$ sınırları içerisinde değişim gösterdiği tespit edilmiştir (Çizelge 2). Üst kabukta ölçülen $\mathrm{L}$, a ve $\mathrm{b}$ değerleri ise sirası ile ortalama olarak 43.51, 26.57 ve 16.07 değerlerinde bulunmuștur (Çizelge 2). Fishcer ve Fishcer (2002) tarafından yapılan çalışmada, Pinova çeşidine ait meyvelerin orta irilikte $(70 \mathrm{~mm}$ çapında ve 130-150 g ağırlığında) olduğu, meyve eti sertliğinin ise ortalama $9.5 \mathrm{~kg} \mathrm{~cm}^{-2}$ olduğu bildirilmiştir. Aynı çeşit üzerine yürütülen farklı çalışmalarda, ortalama meyve ağırlığının 118.7 g (Szklarz, 2004) ve 151.9 g (Kiprijanovski, 2007) olduğu bildirilmektedir. Solomakhin ve Blanke (2010), Pinova çeşidinde, gölgeleme amaçlı kullanılan farklı renkteki tüllerin, meyve eti sertliği üzerine değişimlere sebep olduğunu $\left(8.4-10.2 \mathrm{~kg} \mathrm{~cm}^{-2}\right)$ ve tat oluşumunun, optimum 7.5 - $8.5 \mathrm{~kg} \mathrm{~cm}^{-2}$ aralığında ortaya çıktığını bildirmişlerdir. Aynı çalışmada, üst kabuk L, a ve $b$ değerlerinin sirası ile 21.9 - 41.7, 42.3 51.5 ve 36.8 - 46.8 aralıklarında olduğu rapor edilmiştir. Szklarz (2004) tarafından ise hasat edilen Pinova meyvelerinin \%71'inde kırmızı renk oluşumunun, meyve yüzeyinin \%50' sinden daha fazla alanda meydana geldiği ifade edilmiştir (Szklarz, 2004).

Kimyasal özellikler, bitki bünyesinde çok farklı fizyolojik olaylar içerisine dahil olmakta olup, ürünün duyusal özelliklerinden, hasat sonrası fizyolojisine kadar birçok özellik üzerine etki ediyor olmaları bakımından önem taşımaktadır. Çalışmada incelenen kimyasal özelliklerden; suda çözünebilir kuru madde (SÇKM), titre edilebilir asit (TEA) ve $\mathrm{pH}$ özelliklerinin sırası ile $\% 9.60$ - $14.10, \% 0.38-0.68$ ve 4.26 4.56 arasında olduğu saptanmıştır. Fishcer ve Fishcer (2002), tarafından ise bu aralık sırası ile $\% 12.3$ - 14.9, \% $0.35-0.55$ ve 3.5 - 3.8 olarak tespit edilmiştir. Qing ve ark. (2008), bu çeşide ait SÇKM değerini ortalama \%11.2 olarak bulduklarını bildirirken, Mika ve ark. (2016) ise farklı seyreltme uygulamaları neticesinde, bu özelliğin \%13.4 - 16.7 sinırları içerisinde değişim gösterdiğini rapor etmişlerdir.

Çalışmadan elde edilen sonuçlar genel olarak literatür ile uyumlu tespit edilmiştir. Ancak, yetiştiricilikte ekolojik faktörlerin ve yetiştirici tarafindan tercih edilen kıstasların (hasat zamanı, yetiştiricilik sistemi, kültürel işlemler vb.) bu özellikler üzerine olan etkileri göz ard1 edilmemelidir. Meyve tutum döneminde, serin seyreden hava koşullarının, büyüme konilerinde sentezlenen sitokinini arttırmak süretiyle hücre sayısını arttırdığg ve hücre genişlemesi sonrası bu yörelerde yetişen meyvelerin daha büyük boyutlara ve ağırlığa sahip olduğu ifade edilmektedir. Yetiştirme sezonunun devamında hava sıcaklıkları yüksek ise, meyvelerde yuvarlak yapının oluşmasına sebep olan oksin, düşük ise meyve eksenini uzatan giberellik asit daha fazlaca sentezlenir (Sherman ve Beckman 2002). Bu durum hasat edilen meyvelerin, basık veya uzun şekilli olması üzerine oldukça etkilidir. Özellikle hasada yakın dönemde, gece ve gündüz sıcaklık fark1, 1şık miktarı ve kalitesi ile nem, renklenme üzerine oldukça önemlidir. Hastalık ve zararlı kontrolü meyve biyokimyası bakımından önemli olup, epidemi artışına paralel, özellikle organik ve fenolik asitler, karşı savunma ajanı olarak 
artış göstermektedir (Gunen ve ark., 2005). Hasat, klimakterik meyve türlerinde, yeme olumuna doğru kaydırılırsa, pektin parçalanması sebebiyle meyve eti sertliğinde, organik asit parçalanması sebebiyle ise TEA'da düşüş ve pH'da yükselme meydana gelir (Çolak ve ark., 2019). Meyve tutum miktarının yüksek olması durumunda, pomolojik ve kimyasal özelliklerin miktarında gerilemeler görülür (Mertoğlu ve ark., 2019; Eskimez ve ark., 2020). S1k dikim, güneş 1şınlarının daha etkin kullanımına engel olurken, goble budamanın tercih edilmesi bu bakımdan avantaj sağlamaktadır (Özkan ve Küçüker, 2009). Güneş 1şığ1, hava sirkülasyonu, taç sıcaklığı, nem ve hastalık ile zararlı üzerine etki eden bu faktörler, ürünlerin son hali üzerine önemli etkiler göstermektedir (Usanmaz ve ark., 2018).
Meyve ağaçları uzun ömürlü olup, yetiştiriciliğinde, bitkinin fizyolojik verim çağına ulaşması genel olarak 5-10 yıl sürmektedir. Yetiştiriciliğin sürdürülebilir ve ekonomik olması, bahçe kurulumuna karar verildiği andan itibaren doğru tercihlerin (anaç/çeşit tercihi, dikim sıklığı, budama şekli vb.) yapılması ile mümkündür. $\mathrm{Bu}$ noktada, özelliklerin birbirini nasıl etkilediği oldukça önemli olup, tercihleri şekillendirmektedir. Çalışmada incelenen özelliklerin birbiri ile olan ilişkileri Çizelge 3'te verilmiştir.

Çift çenekli bitkilerde, asimilasyon ürünleri büyüme konilerine ayrrt etmeksizin taşınmaktadır. Çalışmada meyve eni ile meyve boyu arasında tespit edilen yüksek pozitif ilişki $\left(0.87^{* * *}\right)$ bu durum ile paraleldir. Hacimce

Çizelge 3: İncelenen özellikler arasındaki korelasyon katsayıları

\begin{tabular}{|c|c|c|c|c|c|c|c|c|c|c|c|}
\hline & En & Boy & Ağırlık & Sertlik & $\mathrm{L}$ & $\mathrm{a}$ & b & SÇKM & $\mathrm{pH}$ & TEA & Verim \\
\hline Boy & $0.87^{* * *}$ & & & & & & & & & & \\
\hline Ağırlık & $0.97^{* * *}$ & $0.90^{* * *}$ & & & & & & & & & \\
\hline Sertlik & $-0.44^{* * *}$ & $-0.41^{* *}$ & $-0.46^{* * *}$ & & & & & & & & \\
\hline $\mathrm{L}$ & $-0.40^{* * *}$ & $-0.26^{* * *}$ & $-0.39^{* * *}$ & $0.16^{*}$ & & & & & & & \\
\hline $\mathrm{a}$ & $0.43^{* * *}$ & $0.30^{* * *}$ & $0.43^{* * *}$ & $-0.22^{* *}$ & $-0.85^{* * *}$ & & & & & & \\
\hline $\mathrm{b}$ & $-0.31^{* * *}$ & $-0.20^{* *}$ & $-0.31^{* * *}$ & $0.12^{\mathrm{ns}}$ & $0.91^{* * *}$ & $-0.82^{* * *}$ & & & & & \\
\hline SÇKM & $0.13^{\mathrm{ns}}$ & $0.17^{*}$ & $0.15^{*}$ & $-0.06^{\mathrm{ns}}$ & $-0.06^{\mathrm{ns}}$ & $0.07^{\mathrm{ns}}$ & $-0.05^{\mathrm{ns}}$ & & & & \\
\hline $\mathrm{pH}$ & $0.03^{\text {ns }}$ & $0.04^{\mathrm{ns}}$ & $0.04^{\mathrm{ns}}$ & $-0.15^{*}$ & $0.10^{\text {ns }}$ & $-0.03^{\mathrm{ns}}$ & $0.14^{\mathrm{ns}}$ & $-0.09^{\text {ns }}$ & & & \\
\hline TEA & $0.04^{\mathrm{ns}}$ & $0.02^{\mathrm{ns}}$ & $0.03^{\mathrm{ns}}$ & $0.11^{\mathrm{ns}}$ & $-0.16^{*}$ & $0.05^{\mathrm{ns}}$ & $-0.16^{*}$ & $0.15^{*}$ & $-0.78^{* * *}$ & & \\
\hline Verim & $-0.60^{* * *}$ & $-0.51^{* * *}$ & $-0.56^{* * *}$ & $-0.20^{* *}$ & $0.40^{* * *}$ & $-0.46^{* * *}$ & $0.37^{* * *}$ & $-0.17^{*}$ & $0.07^{\mathrm{ns}}$ & $-0.07^{\mathrm{ns}}$ & \\
\hline TCHGS & $0.05^{\mathrm{ns}}$ & $0.04^{\mathrm{ns}}$ & $0.06^{\mathrm{ns}}$ & $-0.03^{\mathrm{ns}}$ & $-0.08^{\mathrm{ns}}$ & $0.05^{\mathrm{ns}}$ & $-0.05^{\mathrm{ns}}$ & $0.02^{\mathrm{ns}}$ & $0.04^{\mathrm{ns}}$ & $-0.01^{\mathrm{ns}}$ & $-0.06^{\mathrm{ns}}$ \\
\hline
\end{tabular}

${ }^{*}: \mathrm{p}<0.05,{ }^{*}: \mathrm{p}<0.01, * * *: \mathrm{p}<0.001$ 
artışı sağlayan meyve boyutları ise ağırlığını arttırmaktadır. Bu bağlamda meyve ağırlığı ile meyve eni ve boyu arasında sirası ile $(0.97 * * *)$ ve $(0.90 * * *)$ düzeylerinde kuvvetli pozitif ilişki tespit edilmiştir. Belirtilen özellikler arasındaki yüksek pozitif ilişki, elmanın da dahil olduğu birçok meyve türünde rapor edilmiştir (Sarıdas ve ark., 2017; Kahya ve Selçuk, 2019; Eskimez ve ark., 2020). Aynı zamanda meyve iriliğinin, hücre büyümesinden ziyade korteksteki hücre sayısının artmasıyla ilişkili olduğu belirtilmiştir (Byers, 2003). İri meyveler ile daha küçük boyuttaki meyveler incelendiğinde, iri meyvelerdeki hücre bölünmesinin fazla olması sebebiyle hücre sayısının da fazla olduğu bilinmektedir (Atay ve ark., 2009). Bu durum, seyreltme işleminin, çok şiddetli olmamakla birlikte hücre çoğalması evresine kaydırılması ile meyve iriliğinin artacağı şeklinde yorumlanabilir.

Meyve hacminde meydana gelen artış, hücreler arası boşluğun artmasına da sebep olduğundan, meyve eti sertliği ile meyve eni $\left(-0.44^{* * *}\right)$, boyu $\left(-0.41^{* *}\right)$ ve ağırlığı $\left(-0.46^{* * *}\right)$ arasında yüksek düzeyde negatif ilişki tespit edilmiştir. Benzer sonuçlar, Eskimez ve ark. (2020), tarafından da bildirilmiştir. $\mathrm{Bu}$ durum, meyve iriliğinin yükselmesine zemin hazırlayan uygulamaların yapılması durumunda hasadın geciktirilmemesi gerektiği ve muhafaza bakımından öncelikli olarak kullanılmaması (yüksek pektinaz enzim aktivitesi ve içsel etilen üretimi sebebiyle) gerektiği şeklinde yorumlanabilir. Nitekim Johnston ve ark. (2002), tarafindan iri elma meyvelerinde, kalite parametreleri kaybının daha hızlı görüldüğü bildirilmektedir.

Verim ile meyve boyutları (meyve eni $-0.60^{* * *}$, meyve boyu $\left.-0.51^{* * *}\right)$, meyve ağırlığı $\left(-0.56^{* * *}\right)$ ve SÇKM (-0.17*) arasında negatif yönlü ilişki tespit edilmiş olup, tüm bu durumlara, verim artışı ile birlikte asimilasyon ürünlerinin, daha fazla meyveye paylaştırılmış olması sebep olmuş olabilir. Fotosentezde, sekonder ürün olarak sentezlenen antosiyaninlerin de verim artışından olumsuz etkilenip $\left(-0.46^{* * *}\right)$, daha fazla meyveye paylaştırılmasına bağlı olarak azalış eğilimi gösterdiği tespit edilmiştir. Antosiyanin birikiminin azalması ile meyve parlaklığ 1 ve zemin rengi hakimiyetini artmaktadır. Bu sebeple, a değeri ile parlaklığ temsil eden $\mathrm{L}\left(-0.85^{* * *}\right)$ ve sarılı̆ ${ }_{1}$ temsil eden b $\left(-0.82^{* * *}\right)$ değerleri arasında güçlü ve negatif korelasyon bulunmuştur. Elde edilen sonuçlar, üretimde standardizasyonun sağlanabilmesi için ürün yükünün ne derece önemli olduğunu işaret etmektedir. Bu sebeple, seyreltme işleminin, yetiştiricilikte mutlak suretle uygulanması gerekmektedir. Meyve tutumunun fazla olmas1 durumunda, meyve iriliğini ve renklenmesini arttıran uygulamalarin hassasiyetle yapılmas1 gerekmektedir. Meyvelere taşınan kuru madde miktarının, verim artışı ile düşüşü, meyvelerde kompakt yapının oluşumunu sekteye uğrattığından, verim ile sertlik arasında da negatif yönlü ilişki tespit edilmiştir $\left(-0.20^{* *}\right)$. Verim artışının, meyvenin pomolojik ve kimyasal özelliklerini, çalışma sonuçları ile benzer şekilde değiştirdiği bildirilmektedir (Öztürk ve ark., 2012; Mertoğlu ve ark., 2019; Yehia ve ark., 2019; Eskimez ve ark., 2020). Toplam organik asitlerin, hakim asit cinsinden hesaplanmış hali olan TEA ile $\mathrm{pH}$ özellikleri arasında kuvvetli ve negatif yönlü ilişki $\left(-0.78^{* * *}\right)$ tespit edilmiştir. $\mathrm{pH}$ ile TEA 
arasındaki negatif ilişki, elmada, Mertoğlu ve Evrenosoğlu (2019), tarafindan $-0.81^{* * *}$ olarak benzer şekilde bildirilmektedir. Tam çiçeklenmeden hasada geçen sürenin uzaması, meyvelerde organik asitlerin parçalanmasını arttırarak, pH’yı yükseltir. Ayrıca TÇHGS'nin uzaması, meyvelerde, pektin ve nişastanın suda eriyebilir şekerlere dönüşümünü arttırır (Ingle ve ark., 2000). Çalışmada, TÇHGS ile açıklanan özellikler arasında aynı eğilim görülmesine rağmen, istatistiksel düzeyde önemlilik saptanmamıştır. Bu duruma, çalışmada elde edilen TÇHGS sürelerinin, dar bir aralıkta tespit edilmiş olmasının sebep olduğu düşünülmektedir.

\section{Sonuç ve Öneriler}

Ülkemiz elma üretimi bakımından iyi bir konumda olmasına rağmen, ihracatta arzu edilen düzeye henüz ulaşılamamıştır. $\mathrm{Bu}$ bağlamda, ekolojiye uygun tür ve çeşitlerin doğru seçimine ilave olarak, ürün kalitesine yön veren uygulamaların da yetiştiricilikte, zamanında ve doğru şekilde yapılması gerekmektedir.

Araştırmada kullanılan Pinova çeşidinin, Isparta ekolojik şartlarına uygun olduğu tespit edilmiştir. Özelliklerin birlikte ele alınması bakımından, titre edilebilir asitlik ve üst kabuk a değerleri önemli bulunmuş olup, birçok özellik ile etkileşim halinde oldukları tespit edilmiştir. Ekolojiye ve yetiştirici şartlarına bağımlı olarak değişen bu özelliklerin, yetiştiricilikte, pratik ve kolay uygulamalar ile kaliteyi arttırıcı şekilde yönlendirilmesi gerektiği söylenebilir. Benzer çalışmaların, farklı tür-çeşit ve ekolojilerde periyodik olarak tekrar edilerek, küresel iklim değişikliği altında etkilerinin ortaya çıkarılmasına devam edilmelidir.

\section{KAYNAKLAR}

Byers RE 2003. Flower and fruit thinning and vegetative: Fruiting balance (pp. 409-436). CABI Publishing, Wallingford, Oxon, UK.

Cennet O, Karaçayır HF 2009. Türkiye'de elma üretimi, tüketimi, pazar yapısı ve diş ticareti. International Journal of Agricultural and Natural Sciences, 2(1): 41-49.

Czynczyk A, Bielicki P, Mika A, Krawiec A 2005. Growth and yielding in six scabresistant apple cultivars grafted on three dwarfing rootstocks in integrated fruit production. Journal of fruit and ornamental plant research. 13(1/4): 19.

Çolak AM, Okatan V, Polat M, Güçlü SF 2019. Different harvest times affect market quality of Lycium barbarum L. berries. Turkish Journal of Agriculture and Forestry. 43(3): 326-333.

Atay E, Pirlak L, Atay AN 2009. Elmalarda Meyve Büyüklüğünü Etkileyen Faktörler. Ege Üniversitesi Ziraat Fakültesi Dergisi. 46(2): 137-144.

Eskimez İ, Polat M, Mertoğlu K 2020. M9 Anacı Üzerine Aşılı Arapkızı, Jonagold ve Fuji Kiku Elma (Malus domestica Borkh.) Çeşitlerinin Isparta Ekolojik Koşullarında Fenolojik ve Fiziko-Kimyasal Özellikleri. Uluslararası Tarım ve Yaban Hayatı Bilimleri Dergisi, (Basımda).

Fishcer M, Fishcer C 2002. Pinova apple cultivar. The Compact Fruit Tree. 35(1): 19-20.

Gunen Y, Misirli A, Gulcan R 2005. Leaf phenolic content of pear cultivars resistant or susceptible to fire blight. Scientia horticulturae. 105(2): 213-221. 
Ingle M, D’Souza MC, Townsend EC 2000. Fruit characteristics of 'York' apples during development and after storage. HortScience, 35(1): 95-98.

Ishiykawa M, Suzuki C, Kitayama H, Sato

T, Kudo N 1991. New apple cultivars "Mellow". Bulletin Aomori Apple Experiment Station. 27: 99-109.

İmrak B, Küden A, Küden AB, Sarıer A 2019.

Effects of different pruning systems on fruit yield and quality in plum (Prunus salicina Lindl.). Turkish Journal of AgricultureFood Science and Technology. 7(11): $1872-1876$.

Jackson ML 1962. Interlayering of expansible layer silicates in soils by chemical weathering. Clays and Clay Minerals. 11(1): 29-46.

Johnston JW, Hewett EW, Hertog ML, Harker FR 2002. Harvest date and fruit size affect postharvest softening of apple fruit. The Journal of Horticultural Science and Biotechnology. 77(3): 355-360.

Karaçalı İ 2012. Bahçe ürünlerinin muhafazası ve pazarlanması. Hasat öncesi dönemde gelişmeyi etkileyen faktörler. Ege Üniversitesi Yayınları. No: 494, 444s, İzmir.

Kiprijanovski M, Arsov T, Gjamovski V, Damovski K 2007. Study of certain introduced apple cultivars in the Prespa region. In I Balkan Symposium on Fruit Growing 825 (pp. 125-132).

Legave JM, Farrera I, Almeras T, Calleja M 2008. Selecting models of apple flowering time and understanding how global warming has had an impact on this trait.
The Journal of Horticultural Science and Biotechnology. 83(1): 76-84.

Li H, Tsao R, Deng Z 2012. Factors affecting the antioxidant potential and health benefits of plant foods. Canadian Journal of Plant Science. 92(6): 1101-1111.

Mertoğlu K, Evrenosoğlu Y 2017. Ateş yanıklığı (Erwinia amylovora) hastalığına dayanıklılık ıslahında, hastalığa karşı testlenmiş $\mathrm{F}_{1}$ melez armut popülasyonunun fenolojik ve meyve özellikleri. Tekirdağ Ziraat Fakültesi Dergisi. 14(3): 104-115.

Mertoğlu K, Evrenosoğlu Y 2019. Bazı Elma ve armut çeşitlerinde fitokimyasal özelliklerin belirlenmesi. Ziraat Fakültesi Dergisi. 14(1): 11-20.

Mertoğlu K, Evrenosoğlu Y, Polat M 2019. Combined effects of ethephon and mepiquat chloride on late blooming, fruit set, and phytochemical characteristics of Black Diamond plum. Turkish Journal of Agriculture and Forestry. 43(6): 544-553.

Mika A, Buler Z, Treder W 2016. Mechanical pruning of apple trees as an alternative to manual pruning. Acta Sci. Pol. Hortorum Cultus. 15(1): 113-121.

Özçatalbaş O, Turhanoğulları Z, Kutlar İ 2009. Dünya elma üretim sektörünün genel durumu ve gelişmeler. International Journal of Agricultural and Natural Sciences. 2(1): 139-144.

Özkan Y, Küçüker E 2009. Bodur elma yetiştiriciliğinde budama ve terbiye teknikleri. International Journal of Agricultural and Natural Sciences. 2(1): $1-9$.

Öztürk B, Özkan Y, Yıldız K, Çekiç Ç, Kılıç 
$\mathrm{K}$ 2012. Red chief elma çeşidinde aminoethoxyvinylglycine'nin (avg) ve naftalen asetik asit'in (naa) hasat önü döküm ve meyve kalitesi üzerine etkisi. Anadolu Tarım Bilimleri Dergisi. 27(3): 120-126.

Qing Z, Ji B, Zude M 2008. Non-destructive analyses of apple quality parameters by means of laser-induced light backscattering imaging. Postharvest Biology and Technology. 48(2): 215-222.

Reig G, Mestre L, Betrán JA, Pinochet J, Moreno MÁ 2016. Agronomic and physicochemical fruit properties of 'Big Top'nectarine budded on peach and plum based rootstocks in Mediterranean conditions. Scientia Horticulturae. 210: 85-92.

Sarıdas MA, Kapur B, Çeliktopuz E, Kargı SP 2017. Irrigation regimes and bio-stimulant application effects on fruit quality features at 'Rubygem' strawberry variety. Turkish Journal of Agriculture-Food Science and Technology. 5(10): 1221-1227.

Sherman WB, Beckman TG 2002. Climatic adaptation in fruit crops. XXVI International Horticultural Congress, Toronto, Canada.

Solomakhin A, Blanke MM 2010. Can coloured hailnets improve taste (sugar, sugar: acid ratio), consumer appeal (colouration) and nutritional value (anthocyanin, vitamin C) of apple fruit?. LWT-Food Science and Technology. 43(8): 1277-1284.

Szklarz M 2004. Evaluation of apple cultivars with different susceptibility to scab (Venturia inaequalis ADERH.). Journal of fruit and ornamental plant research. 12: 89-95.

Taysı MR, Çelik Ş 2017. Elma verimine yer ve çeşit etkisinin faktöriyel denemeler ile belirlenmesi. Türk Tarım ve Doğa Bilimleri Dergisi. 4(3): 250-254.

Tustin DS, Cashmore WM, Bensley RB 2001. Pomological and physiological characteristics of slender pyramid central leader apple (Malus domestica) planting systems grown on intermediate vigour, semi-dwarfing and dwarfing rootstocks. New Zealand Journal of Crop and Horticultural Science. 29: 195-208.

Usanmaz S, Öztürkler F, Helvacı M, Alas T, Kahramanoğlu I, Aşkın MA 2018. Effects of periods and altitudes on the phenolic compounds and oil contents of olives, cv. ayvalik. International Journal of Agriculture Forestry and Life Sciences. 2(2): 32-39.

Yehia TA, Abdel-Mohsen MA, Hussien AM, Hussein HH 2019. Fruit thinning and its effect on yield and quality of apricot fruits" Priana. Middle East Journal of Agriculture Research. 8(4): 1219-1227.

Zar JH 2013. Biostatistical analysis: Pearson New International Edition. Pearson Higher Ed. 